\title{
THE PERCEPTION OF SELECTED ASPECTS OF INVESTMENT ATTRACTIVENESS BY BUSINESSES MAKING INVESTMENTS IN THE CZECH REPUBLIC
}

\author{
Ivan Jáč, Marie Vondráčková
}

\section{Introduction}

Investment attractiveness reflects how interesting the relevant territory, area or region is to businesses. The set of factors influencing the level of investment attractiveness includes both fixed factors (geographic location, deposits of iron ore or large waterways), and factors manageable from the state policy viewpoint (education of the population, investment incentive policies, labour costs and the taxation rate). There are many indicators showing the strengths and weaknesses of a country and its economy, and whether the business environment is suitable for investors or if the business environment is risky and problematic.

This article interprets the results of a survey carried out that looked at the effects of selected investment factors on decisions taken by businesses making FDI (Foreign direct investment) - which means on the investment attractiveness of countries striving for FDI. First, based on a theoretical search, we selected specific factors for the inquiry that have an impact on investment decisions taken by businesses. The factors were subsequently verified through a questionnaire sent to the investors. They were further verified through a regression analysis.

Investment attractiveness refers to the competitiveness of a country within the investment environment, and investment decisions that are made by a business regarding the localization of its investments. Investment attractiveness may be defined as the set of factors that influence a business entity when making its investment decisions. Investment attractiveness reflects how interesting the relevant territory, area or region is to businesses. The set of factors influencing the level of investment attractiveness includes both fixed factors (geographic location, deposits of iron ore or large waterways), and factors manageable from the state policy viewpoint (education of the population, investment incentive policies, labour costs and the taxation rate). There are many indicators showing the strengths and weaknesses of a country and its economy, and whether the business environment is suitable for investors or if the business environment is risky and problematic. This issue is dealt with using the theory of localization.

\section{The Theory of Localization}

The first authors who worked with the theory of localization were Laundardt (1882), von Thünen (1926), Hotteling (1929) and Allonso (1964), and as regards current authors, it has been addressed by Bilington in his book called The Location of Foreign Direct Investment: An Empirical Analysis (1999).

General theory of localization described Hoover (1948), Isard (1956), Greenhut (1959). The specification of localization factors made Dunning (2002) (product, economy activity, region), Rumpel (2008) (capital), Grabow and Henckel (1995) (significant soft location factors), Grabow and Hollbach-Gromig (1995) (environmental quality), Wokoun (2008) (residential structure), Krugman and Obstfeld (2009) (limited resources of the region), Ponikelský (2008) (politico-economic environment) and for example Simango (1993) (taxes) and Wasylenko (1991) (fiscal and monetary policy). The most famous czech autors who worked with theory of localization were Viturka and Damborský. We can name many artists who followed the decisions of investors about the location, but none of them did not examine the direct effects the selected location factors (below) and their influence on the investment decisions of companies.

All theories of localization are based on the condition of perfect competition and the 
search for localization factors, or investment stimuli influencing an investor's decisions when selecting a locality for its investments. The localization factors may be classified into several forms. Weber states the three most significant localization factors: transportation costs, labour costs, and agglomeration effects:

$$
T C=C T+C L+A E
$$

where total costs TC are the sum of transportation costs CT, labour costs CL, and agglomeration effects $A E$. Weber further classifies localization stimuli into general (significant across industries) and special (significant only for a specific industry). He further classifies general stimuli into regional and agglomeration ones. Grabow and Henckel classify the factors into hard and soft, or measurable and unmeasurable, psychological, and sociological. (Žítek, 2010)

A modification to the theory of localization that challenges perfect competition and is based on monopolistic competition where price is the cardinal element (unlike perfect competition models) has been put forth by Palander. Palander proceeds from the price determined by the market position and market size. Monopolistic competition is also dealt with by Losch, who considers the sales market, transportation costs, labour costs, and agglomeration costs to be the most significant localization factors. The theory follows the Hotelling's law. (Holman, 2001)

The latest trend in new localization theories is to account for behavioural attitude. Behavioural attitude includes other stimuli in the localization theory, among them managers' personal preferences.

According to Viturka, localization theories are one of the oldest tools used to assess the quality of a business environment. Viturka distinguishes between four orientations of localization theories: an explanation of localization decisions made by businesses, an examination of the mutual relationships between localization decisions made by businesses, an analysis of the behavioural aspects of localization, and a synthesis of the total spatial structure of an economy. (Viturka, 2010)

\subsection{Factors Influencing Investors' Decisions}

Investors' decisions are influenced by various aspects that motivate an investor to make investments. We classify investment by motivation into vertical and horizontal investments. Motives for horizontal motivation include the effort to increase the market share on the host country market, or decrease the costs connected with access to the host-country market (customs duties or transportation costs). Vertical motives include the cost optimization of individual production phases.

A significant motive for investment lies in the existence of production factors in the given country. Other investment motives include, for instance:

- preventive investments;

- the diversification of activities;

- the company image;

- the company management's personal motivation; and

- the existence of favourable investment incentives in the host country.

An investor seeks specifics about the locality, which will lead to advantages compared to allocating an investment to another locality. The specifics depend on its needs and the needs of its business activities. (Dunning \& Narula, 1998)

FDI is mainly advantageous for countries with a weak economy, for instance for those that do not have a fully-advanced infrastructure or fully-qualified human resources. The countries then compensate for their weaknesses by creating advantages for investors that make the locality more attractive for investment. The advantages can be of either a financial or nonfinancial character (the acquisition of capital, or possibly the free transfer of land).

In general, it is possible to classify factors influencing decisions made by businesses into macro-localization and micro-localization factors. Macro-localization factors include climate conditions, demographic factors, the structure of settlement, and infrastructure. Micro-localization factors include the availability of the investment area, water, energy, etc. It is possible to classify localization factors from the material viewpoint into natural (land, relief, raw materials and fuels), economic (basic funds, connections to the existing industrial structure, and external savings), social (variations in the development, and satisfaction of needs), production (raw materials, energy, and labour), distribution (availability of the market, and the quantity of sales), organizational (concentration, specialization, and integration), 
social-economic (wage level and the position of trade unions), spatial-economic (structure of settlement, and agglomeration effects), and territorial-technical (infrastructure, water, and energy). (Damborský, 2010)

\section{Questionnaire Inquiry}

After completing the theoretic search, the examination continued with an inquiry among the investors. A questionnaire was created that was divided into six sections:

1. Respondent's identification.

2. Investment incentives.

3. Economic environment.

4. Taxation system.

5. Infrastructure.

6. Business environment.

The first section of the questionnaire contained identification details; the questions focused on the respondent's characteristics. The other sections focused on selected investment stimuli influencing the behaviour of businesses during the selection of a locality for making their investment. The questions were targeted at the investment environment in the Czech Republic.

The selection of respondents was based on a database kept by Czechlnvest; it included businesses that had obtained, within foreign direct investment, a subsidy in the form of an investment incentive. The sample of respondents addressed was created applying the rules of representativeness and information capability. However, this factor was then affected by the number of returned questionnaires. In total, we addressed 300 respondents that made investments in the Czech Republic in the period between 2000 and 2015. The group of respondents only contained businesses that were still active in 2015. Out of the 300 respondents addressed, 100 respondents returned completed questionnaires.

The inquiry was targeted at finding out how the selected factors influenced businesses when making a decision on their investment localization - what factors enhance the investment attractiveness of the country in the area of foreign direct investment. What investment stimuli influenced decisions made by the businesses in allocating the investment, and how they assess the stimuli after making investments in the Czech Republic? The inquiry was aimed at obtaining information directly from investors - representatives from management of the businesses that had decided to carry out their investment plan in the Czech Republic through Czechlnvest (Investment and Business Development Agency in Czech Republic). Resulting from this fact, those were businesses from the manufacturing industry that had been granted one of the investment incentives provided in the Czech Republic.

\section{Tab. 1: Investment incentive section}

\begin{tabular}{l|c}
\multicolumn{1}{c}{ Investment incentives } & $\%$ \\
\hline $\begin{array}{l}\text { What is your assessment of the administrative burden to obtaining an investment incentive } \\
\text { in the Czech Republic? }\end{array}$ \\
\hline Small & 7 \\
\hline Big & 29 \\
\hline Reasonable & 42 \\
\hline What investment support did the entity apply for? & 11 \\
\hline Corporate income tax allowance & 47 \\
\hline Transfer of land at a preferential price & \\
\hline Material support for property acquisition & 42 \\
\hline What is your assessment of the investment incentive system in the Czech Republic? \\
\hline Unsatisfactory & 58 \\
\hline Satisfactory
\end{tabular}


As mentioned above, the sample of from the Liberec Region (33\%) and Central respondents addressed was made as Bohemia Region (21\%) with business activities representative; however, only one-third of in the engineering industry (16\%) and the questionnaires were returned. The greatest number of responses arrived from small businesses with up to 50 employees (42\%)

electrical industry $(27 \%)$ as well as in IT and SW development (19\%).

\section{Tab. 2: Economic environment section}

\begin{tabular}{l|c}
\multicolumn{1}{c}{ Economic environment } & $\%$ \\
\hline Are you interested in the economic environment in the Czech Republic? & 63 \\
\hline Yes & 37 \\
\hline No & \multicolumn{2}{|}{} \\
\hline Do you monitor GDP? & 63 \\
\hline Yes & 37 \\
\hline No & \\
\hline Do you monitor inflation? & 63 \\
\hline Yes & 37 \\
\hline No & \\
\hline
\end{tabular}

\section{Tab. 3: Taxation system section}

\section{Taxation system}

Is the taxation system in the Czech Republic complicated for you?

\begin{tabular}{l|c}
\hline Yes, it is. I cannot grasp it. & 17 \\
\hline No, it isn't. It is simple. & 35 \\
\hline Some of the taxes are not fully clear to me. & 25 \\
\hline I am only interested in taxes relating to my business. & 16 \\
\hline I don't know. & 7
\end{tabular}

Do you consider the VAT rates in the Czech Republic to be high - with respect to other areas of your business activities?

\begin{tabular}{l|l}
\hline Yes & 42 \\
\hline No & 21 \\
\hline The rates are reasonable. & 37 \\
\hline
\end{tabular}

Do you consider the individual income tax rates to be high - with respect to the surrounding states?

\begin{tabular}{l|c}
\hline Yes & 39 \\
\hline No & 23 \\
\hline The rates are reasonable. & 38 \\
\hline Do you consider the corporate income tax rates to be high - with respect to the surrounding states? \\
\hline Yes & 37 \\
\hline No & 35 \\
\hline The rates are reasonable & 28 \\
\hline
\end{tabular}




\begin{tabular}{|c|c|}
\hline Infrastructure & $\%$ \\
\hline \multicolumn{2}{|l|}{ What type of transportation do you mostly use as an entity? } \\
\hline Road & 100 \\
\hline \multicolumn{2}{|l|}{ Is this type of transportation in the Czech Republic sufficient for you? } \\
\hline Yes & 50 \\
\hline Mostly yes & 45 \\
\hline No & 5 \\
\hline \multicolumn{2}{|l|}{ Do you need storage areas for your business activities? } \\
\hline Yes & 87 \\
\hline No & 13 \\
\hline \multicolumn{2}{|l|}{ If you need storage space for your business activities, what are they? } \\
\hline Our own storage space & 80 \\
\hline Rented storage space & 25 \\
\hline \multicolumn{2}{|l|}{ If you use rented storage space, are you satisfied with the rental terms and conditions? } \\
\hline Yes & 33 \\
\hline Mostly yes & 17 \\
\hline Mostly no & 5 \\
\hline \multicolumn{2}{|l|}{ Was it easy for your business to get available storage space? } \\
\hline Yes, it was. We rented space close to the business location. & 31 \\
\hline It was difficult to get adequate space; our own space is away from the business location. & 11 \\
\hline Yes, it was. We have our own space close to the business location. & 54 \\
\hline
\end{tabular}

The addressed businesses and their investment plans were most often supported by the following incentives: corporate income tax allowance (42\%) and material support for property acquisition (47\%). More than half $(67 \%)$ of the respondents considered obtaining an investment incentive in the Czech Republic to be too bureaucratic; however, despite this fact, most of the respondents $(58 \%)$ were satisfied with the investment incentive system in the Czech Republic.

Another section of the questionnaire focused on finding out whether the businesses were interested in the economic environment. Most of the respondents $(63 \%)$ answered that they monitored the macroeconomic indicators and were interested in the economic development in the location of their business activities.

The inquired investors considered the tax legislation in the Czech Republic to be rather poorly arranged and complicated (42\%) with a high tax burden ( $42 \%)$.
The infrastructure was another factor examined within the inquiry. All addressed investors used road transportation the most $(100 \%)$.

In the following section of the questionnaire, the respondents were asked questions related to human resources. The investors did not consider the labour costs in the Czech Republic to be high $(66 \%)$. The addressed respondents mostly employed people with secondary education for their business activities (48\%); however, their availability was problematic (34\%).

The inquiry further examined the investors' satisfaction with the business environment in the Czech Republic. The vast majority of the respondents considered the public administration system and its organization to be complicated; they could not grasp it, and often hired advisers. The respondents were also asked a question related to corruption - 


\begin{tabular}{l|c}
\multicolumn{1}{c}{ Human resources } & $\%$ \\
\hline What is your assessment of labour costs in the Czech Republic? & 26 \\
\hline High & 8 \\
\hline Low & 66 \\
\hline Average & 25 \\
\hline $\begin{array}{l}\text { How demanding are your business activities in the Czech Republic from the human resources } \\
\text { education viewpoint? Please provide the percentages of your employees' education levels. }\end{array}$ \\
\hline Primary education & 48 \\
\hline Secondary education & 27 \\
\hline University education & 21 \\
\hline Does the structure of human resources professional qualifications in the Czech Republic meet your \\
entity's needs? & 19 \\
\hline Yes & 36 \\
\hline No & 24 \\
\hline Mostly yes & \\
\hline Mostly no & 34 \\
\hline Is it difficult to get qualified and experienced employees for your business activities? & 22 \\
\hline Yes & 34 \\
\hline No & 10 \\
\hline Mostly yes & \multicolumn{2}{|c}{} \\
\hline Mostly no & $20 u r$ own \\
\hline
\end{tabular}

Source: own

whether they had run up against it within their business activities. A quarter of the respondents did not wish to answer the question; a third of the respondents had run up against corruption within their business activities.

The outcome of the inquiry is presented in a spider diagram (see Fig. 1). The spider diagram shows how businesses perceive selected investment stimuli in the Czech Republic.

Out of the examined investment stimuli, infrastructure is perceived by businesses making investments in the Czech Republic to be the best one. In view of the fact that $100 \%$ of the respondents answered that they used road infrastructure the most, the result is related to it and to access to storage areas. Out of the selected investment stimuli, human resources ended up in second place, followed by the economic environment and health in the Czech Republic. The businesses perceived the taxation system to be the worst stimulus. However, all the selected factors were monitored by the investors and influenced their decisions.

\section{Regression Analysis}

The following objectives were set for statistical verification: "Determination of the significance and effects of selected investment stimuli for businesses making investments in the Czech Republic". This means determining the examined investment stimulus significance for individual investors. The investment stimuli were selected through a literature search.

Based on the literature search, the most significant localization factors were determined. Based on the selected investment stimuli, research hypotheses were determined.

For this part of the research, simple and multiple regression and correlation were chosen. When processing multidimensional files, the question of the relationship and dependence between two or more quantities (statistical indicators) appears. This means 


\section{Ekonomika a management}

\section{Tab. 6:}

\section{Business environment section}

\section{Business environment}

What is your assessment of the approach of the public authorities you cooperate with within your business activities? (the tax office, state-established or state-supported institutions and agencies, the courts, local public authorities, etc.)?

\begin{tabular}{l|c}
\hline The public authorities are helpful. & 65 \\
\hline We often run up against reluctance to cooperate. & 35
\end{tabular}

What is your assessment of the public administration system in the Czech Republic you cooperate with within your business activities? (the tax office, state-established or state-supported institutions, etc.)?

\begin{tabular}{l|c}
\hline The organization of public authorities is very complicated. & 87 \\
\hline The organization is well-arranged. & 13
\end{tabular}

What is your assessment of the business environment in the Czech Republic from the administrative burden viewpoint?

\begin{tabular}{l|c}
\hline Very demanding, a high degree of bureaucracy & 52 \\
\hline Somewhat demanding & 37 \\
\hline Not very demanding & 11 \\
\hline
\end{tabular}

Have you run up against corruption (whether directly or by hearsay) within your business activities?

\begin{tabular}{l|c}
\hline Yes & 31 \\
\hline No & 47 \\
\hline Idon't wish to answer. & 22 \\
\hline
\end{tabular}

Fig. 1: Inquiry into the perception of investment stimuli by businesses

\section{Perception of investment incentives}

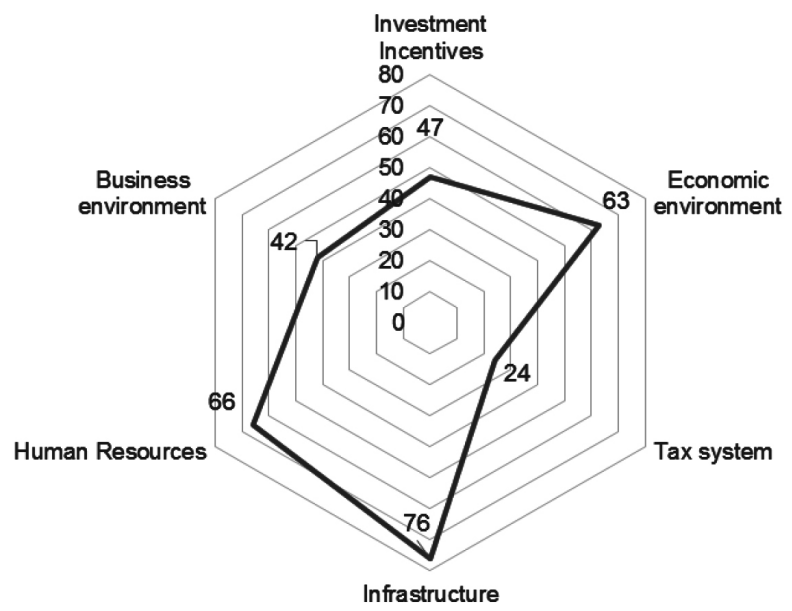


$\mathrm{H} 1$ : FDI is influenced by the values of the macroeconomic indicators in the country where the investment is made.

$\mathrm{H} 2$ : FDI is influenced by the tax burden in the country where the investment is made.

$\mathrm{H} 3$ : FDI is influenced by the condition of the infrastructure in the country where the investment is made.

$\mathrm{H} 4$ : FDI is influenced by the level of the business environment in the country where the investment is made.

an examination of the relationship between quantity $Y$ (dependent variable) and one or more quantities $X$ (independent variable(s)) called explanatory. The matter is dealt with using the regression and correlation analyses, which determine the form of dependence and express it with a function - regression task, and which further determine the degree of dependence correlation task. The dependence may be either functional or statistical. Functional dependence means cases where, regarding the value of one indicator, there is always one value of another indicator corresponding to it. However, we mostly experience statistical dependence where, regarding the value of one indicator, there are several values of another indicator corresponding to it.

The basic case of statistical dependence consists in simple dependence, the dependence between two random quantities, $\mathrm{X}$ and $\mathrm{Y}$. When taking more independent quantities into consideration, we call it multiple (multifold) dependence.

The simplest linear regression model assumes that the relationship between the dependent and independent quantities is linear.

$$
y=\alpha+\beta x
$$

where $\alpha$ (absolute term) and $\beta$ (slope of a line) are parameters of the equation of a line. However, this is not a realistic description of statistical dependence. In view of the random character of dependence, the points do not lie directly on the line, but are instead around it. In order to show relevant deviations, it is necessary to insert a random element, e-residuum, into the equation. This then gives rise to a probability model of simple linear regression.

$$
y=\alpha+\beta x+e
$$

As regards random elements e, they have a normal distribution with an expected value of zero and a constant variance $\sigma^{2}$, where $\alpha$, $\beta$ and $\sigma^{2}$ are unknown parameters of the basic file that must be estimated by means of $n$ independent observations of $X$ and $Y$ quantities. Point estimations $a$ and $b$ of parameters $\alpha$ and $\beta$ of the regression line are determined through the least-square method. The least-square method is based on the requirement to minimize the sum of squared deviations of the observed values from the estimated function:

$$
S=\sum_{i=1}^{n}\left(y_{i}-\alpha-\beta x_{i}\right)^{2}
$$

The minimum point may be determined through annulment of the partial derivative of function $S$ by $\alpha$ and $\beta$. Using this modification, we get a system of normal equations, and through solving it, we get the estimation line.

$$
y^{\prime}=\alpha+\beta x
$$

Deviations

$$
d_{i}=y_{i}-y_{i}^{\prime}
$$

where $y_{i}$ determines empirical or observed values $\mathrm{Y}$; and $\mathrm{y}_{\mathrm{i}}^{\prime}$ show levelled values calculated from the regression line equation, which are called residues. Through the residual sum of squares

$$
S_{r}=\sum_{i=1}^{n} d_{i}^{2}
$$

it is possible to determine the residual variance:

$$
S_{r}^{2}=\frac{S_{r}}{n-2}=\frac{\sum_{i=1}^{n}\left(y_{1}-\alpha-\beta x_{i}\right)^{2}}{n-2}
$$

which is a point estimation of the variance of $\sigma^{2}$ and shows the dispersal of quantities $Y$ about the regression function. The degree of 
dependence is expressed with a determination coefficient calculated under relationship no. 7 , and evaluated in accordance with the table of determination coefficient values. (Mielcová \& Stoklasová, 2012)

$$
R_{y x}^{2}=1-\frac{S_{e}}{S_{t}}
$$

where $S_{e}$ is the proportion of the residual sum of squares, and $S_{t}$ is the total sum of squares. In a linear regression model with an absolute term, the value of $\mathrm{R}^{2}$ lies in the $<0 ; 1>$ interval, and it shows the proportion of variations in the observation of the independent quantity explained through regression. The higher the values, the greater the success rateof regression. In the case of functional dependen$\mathrm{ce}$, it equals 1 ; in the case of independence, it equals 0 . The closer it approaches 1 , the stronger the dependence is considered to be, and therefore to be a well-expressed selected regression function. (Cyhleský, 2009)

\section{Tab. 8: Evaluation of dependence through $\mathbf{R}^{2}$}

\begin{tabular}{l|l}
$\mathrm{R}^{2}<10 \%$ & low proximity \\
\hline $10 \% \leq \mathrm{R}^{2}<25 \%$ & moderate proximity \\
\hline $25 \% \leq \mathrm{R}^{2}<50 \%$ & significant proximity \\
\hline $50 \% \leq \mathrm{R}^{2}<80 \%$ & great proximity \\
\hline $80 \% \leq \mathrm{R}^{2}$ & utmost proximity \\
\hline
\end{tabular}

Source: Cyhelský, 2009

We next applied multiple regression and correlation. It is assumed that the value of an observed indicator results from the effects of many different factors. So we examined how several independent factors influence the concurrently explained variable $\mathrm{Y}$. The dependence of $Y$ on quantities $X_{1}$ to $X_{k}$ may be expressed as

$$
y_{i}=f\left(x_{i 1}, \ldots, x_{i k}\right)+e_{i},(i=1,2, \ldots, n)(10)
$$

where $f\left(x_{i 1}, \ldots, x_{i k}\right)$ is a regression function, and $e_{i}$ is a random error. As regards random errors $e$, we assume that they are independent quantities with an identical distribution. The regression function form for a multiple linear regression model is as follows:

$$
\begin{aligned}
& f\left(x_{i 1}, \ldots, x_{i k}\right)=\beta_{0}+\beta_{1} x_{i 1}+\cdots \\
& \cdots+\beta_{k} x_{i k}
\end{aligned}
$$

Coefficients $\beta_{0}, \beta_{1}, \ldots, \beta_{k}$ are generally unknown coefficients that need to be estimated. The estimation is carried out using the leastsquare method, which is used for simple dependence.

$$
S=\sum_{i^{\prime}=1}^{n}\left(y_{i}-\beta_{o}-\beta_{1} x_{i 1}-\cdots-\beta_{k} x_{i k}\right)^{2}
$$

Function

$$
y^{\prime}=b_{0}+b_{1} x_{1}+b_{2} x_{2}+\cdots+b_{k} x_{k}
$$

is a selective regression function that represents an estimate of the theoretical regression function. The characteristics for measuring the proximity of the multiple linear dependence of $Y$ on independent variables $X$ are similar to those for simple dependence. The proportion

$$
R_{y x_{1} \ldots x_{k}}^{2}=\frac{\sum_{i=1}^{n}\left(y_{i}^{\prime}-\bar{y}\right)^{2}}{\sum_{i=1}^{n}\left(y_{i}-\bar{y}\right)^{2}}=1-\frac{\sum_{i=1}^{n}\left(y_{i}-y_{i}^{\prime}\right)^{2}}{\sum_{i=1}^{n}\left(y_{i}-\bar{y}\right)^{2}}
$$

is a coefficient of multiple determination. Its root shows the coefficient of multiple correlation. A zero value $R_{y x_{1} \ldots x_{k}}^{2}$ means that no linear dependence exists between $Y$ and $X$. It equals 1 in the case of linear functional dependence.A significance test of the selective coefficient of multiple correlation $R$ shows whether a significant relationship exists between the dependent and independent variables. The test is based on the following test criterion

$$
F=\frac{R^{2}}{1-R^{2}} * \frac{n-k-1}{k}
$$


The critical range is defined as follows

$$
K=\left\{F>F_{\alpha(k ; n-k-1)}\right\}
$$

where $F_{\alpha(k ; n-k-1)}$ is a tabulated critical value of the F-division.

In the case of multiple regression, we first verify whether it is possible to correlate selected quantities through the correlation matrix. By that we avoid distortion of the model - if functional dependence exists between the explanatory variables themselves, it is necessary to decide which variables will remain in the model, and which ones will not. A correlation between the independent variables higher than 0.8 is undesirable. In such a case, we talk about multicollinearity. If we find multicollinearity, we will eliminate, based on the model, the which variable from the pair of correlated explanatory variables logically does not fall into the task, or which variable has a weaker correlation with the variable y being explained. (Popelka, 2015)

We begin with hypothesis $\mathrm{H} 1$ and test if the amount of investment incentives $\left(\mathrm{y}_{\mathrm{FDI}}\right)$ depends on selected macroeconomic indicators: GDP $\left(\mathrm{x}_{\mathrm{GDP}}\right)$, rate of inflation $\left(\mathrm{x}_{\mathrm{i}}\right)$, and current account balance $\left(x_{c a}\right)$ : H1: FDI is influenced by the values of macroeconomic indicators in the country where the investment is being made. We set hypothesis $\mathrm{H} 1_{0}$ at zero: FDI is not influenced by the values of macroeconomic indicators in the country where the investment is being made. We confirm or turn down hypothesis $\mathrm{H} 1$.

As regards multiple correlation, we first set a correlation matrix to determine mutual relationships between the independent variables; see multicollinearity above.

\section{Tab. 9: Correlation matrix for H1, the Czech Republic}

\begin{tabular}{l|c|c|c|c} 
& $\mathbf{y}_{\text {FDI }}$ & $\mathbf{x}_{\text {GDP Cz }}$ & $\mathbf{x}_{\mathbf{i} \mathrm{Cz}}$ & $\mathbf{x}_{\mathrm{ca} \mathrm{CZ}}$ \\
\hline $\mathrm{y}_{\mathrm{FDI}}$ & 1 & & & \\
\hline $\mathrm{x}_{\mathrm{GDP} \mathrm{CZ}}$ & 0.8148 & 1 & & \\
\hline $\mathrm{x}_{\mathrm{i} \mathrm{CZ}}$ & -0.4217 & -0.0843 & 1 & \\
\hline $\mathrm{x}_{\mathrm{ca} \_\mathrm{Cz}}$ & 0.7091 & -0.4102 & -0.2458 & 1 \\
\hline
\end{tabular}

\section{Tab. 10: Regression statistics for H1, the Czech Republic}

\begin{tabular}{l|r} 
Determination coefficient & 0.1169 \\
\hline P statistics & 0.6702 \\
\hline
\end{tabular}

The table clearly shows that the dependence does not demonstrate multicollinearity, so we can continue testing.

We describe a multiple linear regression line by the following relationship:

$$
\begin{aligned}
& \mathrm{y}_{\mathrm{FDI} C \mathrm{CZ}}=8597.89+309.692^{*} \mathrm{x}_{\mathrm{CA} \_\mathrm{CZ}}+ \\
& +0.0306146^{*} x_{\text {HDP C } C Z}-397.33^{*} y_{\text {I C }}
\end{aligned}
$$

The results of the regression can be interpreted so that the determination coefficient for this model is $R^{2}=0.1169$, which means very low dependence. Coefficient $\beta_{1}$ being at a confidence level of 0.05 is statistically insignificant as the value of $P$ is greater than 0.05 . Therefore, we accept the zero hypothesis; we can state that in the case of the testing being carried out, the amount of FDI does not show significant dependence on the selected economic indicators.

Values of $\mathrm{P}$ are greater than the confidence level of 0.05 , thus they are statistically insignificant. Therefore, we accept the zero hypothesis; we can state that in the case of the testing being carried out, the amount of FDI does not show significant dependence on the selected economic indicators. FDI is not influenced by the values of macroeconomic 


\section{Ekonomika a management}

indicators in the country where the investment is being made.

We continue with hypothesis $\mathrm{H} 2$ and test if the amount of investment incentives $\left(\mathrm{y}_{\mathrm{FD}}\right)$ depends on the tax burden in the host country: the percentage of VAT in GDP $\left(x_{V A T}\right)$, the percentage of VAT in total taxation $\left(x_{\text {VAT2 }}\right)$, the percentage of individual income tax in GDP $\left(x_{t p}\right)$, and the percentage of corporate income tax in GDP $\left(x_{t c}\right)$ : H2: FDI is influenced by the tax burden in the country where the investment is being made. We set hypothesis $\mathrm{H}_{2}$ at zero: FDI is not influenced by the values of macroeconomic indicators in the country where the investment is being made. We confirm or turn down hypothesis $\mathrm{H}_{2}$.

\section{Tab. 11: Correlation matrix for H2, the Czech Republic}

\begin{tabular}{|c|c|c|c|c|c|}
\hline & $y_{\mathrm{FDI} \mathrm{Cz}}$ & $\mathbf{X}_{\text {vat } \mathrm{cz}}$ & $x_{\text {vat2 } c z}$ & $\mathbf{x}_{\text {tp } \mathrm{Cz}}$ & $\mathbf{x}_{\mathrm{tc} \mathrm{cz}}$ \\
\hline $\mathrm{y}_{\mathrm{FDI} C \mathrm{CZ}}$ & 1 & & & & \\
\hline $\mathrm{x}_{\text {vat } \mathrm{Cz}}$ & 0.8869 & 1 & & & \\
\hline$x_{\text {vat2 } c z}$ & -0.9634 & -0.9769 & 1 & & \\
\hline$x_{\text {tp } \mathrm{Cz}}$ & -0.9123 & -0.9285 & 0.8455 & 1 & \\
\hline$x_{t c C z}$ & -0.9429 & -0.7668 & 0.9592 & 0.7693 & 1 \\
\hline
\end{tabular}

\begin{tabular}{|c|c|c|c|}
\hline Tab. 12: & $\begin{array}{l}\text { Correlation matrix for } \mathrm{H} 2, \mathrm{t} \\
\text { multicollinearity }\end{array}$ & lic - af & \\
\hline & $\mathbf{y}_{\mathrm{FDI} C \mathrm{Cz}}$ & $\mathbf{X}_{\text {vat_cz }}$ & $\mathbf{x}_{\mathrm{tc} \_\mathrm{Cz}}$ \\
\hline$y_{\mathrm{FDICZ}}$ & 1 & & \\
\hline$x_{\text {vat_Cz}}$ & -0.9498 & 1 & \\
\hline$x_{\text {tc } c z}$ & -0.6216 & 0.3478 & 1 \\
\hline
\end{tabular}

\section{Tab. 13: Regression statistics for H2, the Czech Republic}

Determination coefficient
P statistics

In this case, the model contains multicollinearity. It is desirable to eliminate the explanatory variables with great mutual dependence from the model. We eliminate the percentage of VAT in total taxation, and eliminate physical persons' taxation - legal entities' taxation is a more significant indicator for us regarding decisions made by businesses.

Now the model is ready, and we will continue testing.

The regression line form is as follows:

$$
\begin{aligned}
& y_{\text {FD__Cz }}=-9173.39+2518.55^{*} x_{\text {tc_Cz }}+ \\
& +534.394^{*} x_{\text {vat_Cz }}
\end{aligned}
$$

0.1753

0.2856

\begin{tabular}{r|r}
0.1753 \\
\hline 0.2856 \\
\hline Source: own
\end{tabular}

The results of the regression can be interpreted in the way that the determination coefficient for this model is $R^{2}=0.1753$, and $P$ statistics is 0.2856 , which means greater than 0.05. In view of the value of statistics $P$, we accept the zero hypothesis.

We continue with hypothesis $\mathrm{H} 3$ and test if the amount of investment incentives $\left(\mathrm{y}_{\mathrm{FDI}}\right)$ depends on the condition of the infrastructure in the country where the investment is made: percentage of investment in the infrastructure in GDP $\left(x_{\text {iff }}\right)$. We set hypothesis $\mathrm{H}_{3}$ : FDI is not influenced by the condition of the infrastructure 


\section{Tab. 14: Regression statistics H3}

\begin{tabular}{l|l|c|c} 
& Regression line & $\mathbf{R}^{2}$ & P statistics \\
\hline $\mathrm{CZ}$ & $\mathrm{y}_{\mathrm{FDI} \mathrm{CZ}}=4487.88+1108.45^{*} \mathrm{x}_{\text {if } \_\mathrm{CZ}}$ & 0.02704 & 0.5428 \\
\hline
\end{tabular}

Source: own

in the country where the investment is made; we confirm of turn down hypothesis $\mathrm{H}_{0}$. In view of the fact that we have one independent variable only in this model, we are not interested in the correlation matrix. Multicollinearity cannot arise there.

The results of the regression can be interpreted in the way that the determination coefficient for this model is $\mathrm{R}^{2}=2.7 \%$ for the Czech Republic. We accept hypothesis $\mathrm{H}_{0}$ - FDI does not depend on the condition of the infrastructure.

We continue with hypothesis $\mathrm{H} 4$ and test if the amount of investment incentives $\left(\mathrm{y}_{\mathrm{FDI}}\right)$ depends on human resources condition: unit labour costs $\left(\mathrm{x}_{\mathrm{wt}}\right)$, unit wage costs $\left(\mathrm{x}_{\mathrm{ulc}}\right)$, GDP per hour worked $\left(\mathrm{x}_{\mathrm{WH}}\right)$, and rate of unemployment $\left(x_{\text {unemp }}\right)$ : H4: FDI is influenced by the condition of the business environment in the country where the investment is made. We set hypothesis $\mathrm{H}_{4}$ : FDI is not influenced by the condition of human resources in the country where the investment is made. We confirm or turn down hypothesis $\mathrm{H}_{0}$. For a multi-regression model, first we again set a correlation matrix but multicollinearity did not appear.

\section{Tab. 15: Regression statistics H4}

\begin{tabular}{c|l|c|c} 
& \multicolumn{1}{|c|}{ Regression line } & $\mathbf{R}^{\mathbf{2}}$ & P statistics \\
\hline $\mathrm{CZ}$ & $\begin{array}{l}\mathrm{y}_{\mathrm{FDI} C \mathrm{CZ}}=18646.8-148.442^{*} \mathrm{x}_{\mathrm{ULC} \_\mathrm{CZ}}-595.813^{*} \mathrm{x}_{\text {unemp_Cz }}+ \\
+11.9384^{*} \mathrm{x}_{\text {wh_Cz }}+0.276848^{*} \mathrm{x}_{\text {wt_CZ }}\end{array}$ & 0.0639 & 0.9484 \\
\hline
\end{tabular}

Source: own

The results of the regression can be interpreted in the way that the determination coefficient for this model is $R^{2}=6 \%$. We accept that hypothesis $\mathrm{H}_{0}-\mathrm{FDI}$ does not depend on the condition of the infrastructure.

\section{Conclusion}

As stated in the Introduction, when an investor is making a decision on where to make its investment, there is a large number of factors that influence this decision to various extents. Those factors are generally called investment stimuli.

This article evaluates the inquiry into the perception of selected localization stimuli by investors. The inquiry was targeted at investors making investments in the Czech Republic. In total, we addressed 300 respondents; $30 \%$ of them answered. The questionnaire was divided into thematic sections. The inquiry shows that businesses prefer investment incentives in the forms of an income tax allowance and material support for property acquisition. More than half of the respondents consider obtaining an investment incentive in the Czech Republic to be too bureaucratic; however, despite this fact, the majority of the respondents are satisfied with the investment incentive system in the Czech Republic. Most of the respondents answered that they monitored macroeconomic indicators, and were interested in the economic development in the place where their business activities are being conducted The inquired investors consider the tax legislation in the Czech Republic to be rather poorly arranged and complicated; however, they monitor taxes within their business activities or have their own tax advisors. All addressed investors use road transportation the most. The addressed respondents mostly employ, for their business activities, people with a secondary education; however, their availability is problematic. The investors state that it is not easy to get adequate reliable employees with relevant education. The vast majority of the respondents consider the public administration system and 
its organization to be complicated; they cannot grasp it, and often hire advisers. The investors generally assess the investment environment in the Czech Republic as being good, without any significant problematic aspects that would directly discourage them from making an investment in the Czech Republic. The questionnaire confirms that the investors are interested in the selected stimuli within the investment environment, and that the stimuli influence their decisions.

In the statistical section, we verified the hypotheses that had been set. The hypotheses were verified using linear regression - simple and multiple. As regards the dependant variable - that being explained - we chose the amount of FDI in individual V4 countries for the 1998-2014 reference period, and regarding independent variables (explanatory) we chose individual indicators - see the investment stimulus analyses. The first hypothesis $\mathrm{H} 1$ : "FDI is influenced by the values of the macroeconomic indicators in the country where the investment is being made" was not confirmed. All values coming from the model are statistically insignificant; the proximity is not significant. So we can state that FDI does not depend on the values of macroeconomic indicators. As regards $\mathrm{H} 2$ - "FDI is influenced by the tax burden in the country where the investment is being made", the hypothesis was turned down - the results were not statistically significant. We can state that FDI is not influenced by the condition of the infrastructure. We arrived at the same result regarding the third and fourth hypotheses. The impact of the selected factors was not confirmed by the research.

\section{References}

Alonso, W. (1964). Location and Land Use. Cambridge: Harvard University Press.

Bilington, N. (1999). The location of foreign direct investment: an empirical analysis. Applied Economics. Routledge: Taylor \& Francis Group.

Cyhelský, L., \& Souček, E. (2009). Základy statistiky. Praha: Vysoká škola finanční a správní.

CZECHINVEST. (2013, May 6). Investiční pobídky. Retrieved from http://www.czechinvest. org/data/files/ipo-brozura-obalka-cz-cervenec2014-final-3297.pdf.

Damborský, M. (2010). Lokalizace podnikatelských aktivit (Doctoral dissertation). Retrieved from database of Vysoká škola ekonomická.
Damborský, M., \& Wokoun, R. (2010). Lokalizační faktory malého a středního podnikání v podmínkách ekonomiky ČR. E\&M Ekonomie a Management, 13(2), 32-43.

Dunning, J. H., \& Narula, R. (1998). Globalisation and New Realities for Multinational Enterprise: Developing host country interaction. Oslo: University of Oslo.

Grabow, B., Henckel, D., \& Hollbach-Gromig, B. (1995). Weiche Standortfaktoren. Schriften des Deutschen Institut für Urbanistik Band, 89. Stuttgart-Berlin-Köln: Dt. Gemeindeverlag.

Greenhut, M. L. (1959). Plant Location in Theory and Practice. Chapel Hill, NC: University of North Carolina Press.

Holman, R. (2001). Dějiny ekonomického myšlení. Praha: C. H. Beck.

Hoover, E. (2011). The Location of Economic Activity. London: McGraw Hill Book Company Inc.

Hotteling, H. (1929). Stability in competition. Economic Journal, 39(153), 41-57. doi:10.2307/2224214.

Isard, W. (1956). Location and spaceeconomy. Cambridge: Massachusetts Institute of Technology.

Krugman, P. (1990). Increasing returns and economic geography. Journal of Political Economy, 99(3), 483-499. doi:10.1086/261763.

Laundart, W. (1882). Die Bestimmung des Zweckmässigsten Standortes einer Gewerblichen Anlage. Zeitschrift des Vereines Deutscher Ingenieure.

Mielcová, E., Stoklasová, R., \& Ramík, R. (2012). Statistické programy. Slezská univerzita v Opavě: Obchodně podnikatelská fakulta v Karviné.

Ponikelský, P., Koštejnová, Z., \& Kupka, V. (2011, August 19). Ekonomika municipalit a regionů. Retrieved from http://www.vsrr.cz/ reg/kestazeni/emr2.pdf.

Popelka, J. (2015, September 2). Statistika. Retrieved from http://most.ujep.cz/ popelka.

Rumpel, P., Slach, O., \& Kotský, J. (2008). Měkké faktory regionálního rozvoje. Ostrava: Repronis.

Simango, C. (1993). Strategic locational factors influencing foreign investment. European Business Review, 93(4), 12-18. doi:10.1108/EUM0000000001917.

Viturka, M. (2010). Kvalita podnikatelského prostředí, regionální konkurenceschopnost a strategie regionálního rozvoje České republiky. Praha: Grada. 
Wasylenko, M. (1991). Empirical Evidence on Interregional Business Location Decisions and the Role of Fiscal Incentives in Economic Development. In H. W. Herzog, \& A. M. Schlottmann (Eds.), Papers of a conference Industry location and public policy (pp. 15-30). Tennessee: University of Tennessee. prof. Ing. Ivan Jáč, CSc. Technical University of Liberec Faculty of Economics Department of Business Economics and Management ivan.jac@tul.cz

Ing. Marie Vondráčková Technical University of Liberec

Faculty of Economics

Department of Business Economics and Management 


\title{
Abstract
}

\section{THE PERCEPTION OF SELECTED ASPECTS OF INVESTMENT ATTRACTIVENESS BY BUSINESSES MAKING INVESTMENTS IN THE CZECH REPUBLIC}

\author{
Ivan Jáč, Marie Vondráčková
}

Investment attractiveness refers to the interest of the territory, area and region. Investment attractiveness refers to the competitiveness of a country within the investment environment, and investment decisions that are made by a business regarding the localization of its investments. Investment attractiveness may be defined as the set of factors that influence a business entity when making its investment decisions. Investment attractiveness reflects how interesting the relevant territory, area or region is to businesses. The set of factors influencing the level of investment attractiveness are both factors that are fixed (geographic location, deposits of iron ore, large water flows) and, secondly, the factors that from the perspective of state policy influenced (educated population, a policy of investment incentives, labor costs, tax rate, macroeconomic indicators - inflation, GDP and labor productivity). There are many indicators showing the strengths and weaknesses of a country and its economy, and whether the business environment is suitable for investors or if the business environment is risky and problematic. This issue is dealt with using the theory of localization.

This article interprets the results of a survey carried out that looked at the effects of selected investment factors on decisions taken by businesses making FDI - which means on the investment attractiveness of countries striving for FDI. First, based on a theoretical search, we selected specific factors for the inquiry that have an impact on investment decisions taken by businesses. The factors were subsequently verified through a questionnaire sent to the investors. They were further verified through a regression analysis.

Key Words: Investment attractiveness, investors, investment, research, foreign direct investments, investment stimulus, localization.

JEL Classification: F4.

DOI: 10.15240/tul/001/2017-3-008 